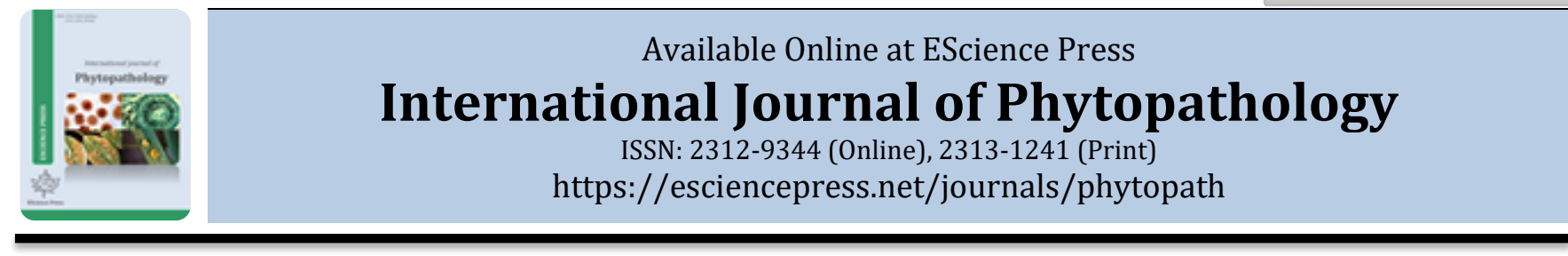

\title{
ASSESSMENT AND DISTRIBUTION OF FOLIAR AND SOIL-BORNE DISEASES OF CAPSICUM SPECIES IN ETHIOPIA
}

Tajudin A. Mohammed, Alemayehu H. Welderufael, Bayoush B. Yeshinigus Ethiopian Institute of Agricultural Research, Ambo Agricultural Research Centre, Ambo, Ethiopia.

ART ICLE I N F O

Article history

Received: June 08, 2021

Revised: August 17, 2021

Accepted: August 23, 2021

Keywords

Fungal diseases

Soil-borne diseases

Foliar diseases

Pepper

Phytophthora capsici
A B S T RA C T

Diseases caused by fungi and oomycetes lead to reduced productivity of pepper (Capsicum spp.) in Ethiopia. Currently, knowledge about severity and geographical distribution of fungal diseases in pepper producing areas is limited. Thus this study was aimed: to map the geographical distribution of economically relevant Capsicum diseases and to identify, document, prioritize, and update the status of fungal infectious diseases across the country. A survey was conducted throughout major pepper agro-ecological zones in Ethiopia for two consecutive years, 2018 and 2019/20. Districts were surveyed based on pepper production at intervals of 4 to 10 kilometers from each sampling zone of major pepper growing areas. Global positioning system (GPS) was used to mark each sampling point using a GPS receiver for altitude and coordinates. Nine major pathogenic fungi were identified in samples collected from different pepper-producing areas across the country. Cercospora leaf spot caused by Cercospora capsici was found prevalent in 39.8\% of the 133 fields studied, followed by Fusarium wilt caused by Fusarium oxysporum f. sp. capsici, and Phytophthora collar, root, and fruit rot caused by Phytophthora capsici, prevalent in $21.1 \%$ and $15.8 \%$ fields, respectively. The maximum overall mean percent severity index $(69.5 \%)$ was recorded for Fusarium stem and root rot (Fusarium solani) followed by damping-off (56.7\%) and Fusarium wilt (55.4\%). The current study indicated the importance of fungal diseases, particularly soil-borne diseases. The molecular characterizations, primers development for important pathogens, and genome-wide screening of Capsicum genotypes in Ethiopia required to advance environmentally safe and affordable disease control methods.

Corresponding Author: Tajudin A. Mohammed

Email: tajudinaliyi2014@gmail.com

(C) The Author(s) 2021.

\section{INTRODUCTION}

Capsicum (Capsicum spp.), also known as pepper, is a major vegetable and spice crop that originated in the American tropics and is now grown for fresh, dried, and processed products worldwide (Bosland et al., 2012). Due to the significant variation in many traits, which makes this crop extremely versatile and suitable for innumerable applications, there is growing interest and fascination in the genus Capsicum for innumerable uses as food and non-food products (Bosland et al., 2012).
The genus Capsicum includes over 30 species, five of which (C. annuum, C. frutescens, C. chinense, C. baccatum, and $C$. pubescens) are domesticated and mainly grown for various purposes (Tripodi and Kumar, 2019).

Currently, the importance of pepper is increasing. They are high value spice and industrial raw material to produce oleoresin commodity and have been given top priority in vegetable research in Ethiopia (Dessie et al., 2019). Small-scale farmers and commercial growers could grow the crop for its fruits in different regions of 
the country. It is produced both during the rainy and dry seasons under supplemental irrigation (Lemma, 2002). A world average production of $32.3 \mathrm{t} /$ ha green and 3.8 t/ha dry pepper are reported (FAO, 2019). In Ethiopia, average dry (red) and green (fresh) hot pepper production is $1.8 \mathrm{t} / \mathrm{ha}$ and $5.9 \mathrm{t} / \mathrm{ha}$, respectively (CSA, 2020), which is outlying below the world's average. In 2020 , the overall area used to cultivate green and red pepper in Ethiopia was 185,872.63 ha with an estimated total production of $380,318.87$ tonne. Remarkably, this data shows that pepper covers $77.91 \%$ of all the areas under vegetables in Ethiopia (CSA, 2020).

Generally, crop yield losses due to pests are estimated to be approximately $35 \%$ in major crops, and may exceed $50 \%$ in some regions where pests control options are limited (Mulaa et al., 2018). Despite the importance of pepper crop in Ethiopia, complete failure of yield due to diseases is common, and farmers are often forced to stop producing due to high disease pressure in the field (Tameru et al., 2003; Mihajlovic et al., 2017), and it causes losses of $25-90 \%$. Among hot pepper diseases, powdery mildew, leaf blight, Wilt and Pepper mottle virus were reported in Ethiopia (Korobkon et al., 1985; BARC, 2000; Sadessa et al., 2016). Recently, wilt-causing pathogens are getting the leading problems of pepper that reported by causing $86.4 \%$ wilt incidence of Ethiopia (Assefa et al., 2015). The wilt disease, incited by several pathogens, is the devastating soil-borne disease and hence difficult to manage. The disease has been observed to be caused by Fusarium spp (Fusarium oxysporum f. sp. capsici and Fusarium solani), Verticillium sp., Phytophthora capsici and Rhizoctonia solani (Rather et al., 2012; AARC, 2019). The diseases that infect and damage pepper fluctuate rely on ecological factors, varietal variations, and microorganisms involved. The investigation conducted in West Gojjam, one of the major pepper growing zones in Ethiopia, stated that just one type of peasant farm variety, marekofana, was discovered to be infected with low to high levels of several fungal leaf, stem, and root diseases, with root rot/wilt complex infections being found practically all of the surveyed sites (Abebe and Abera, 2019). Kebede and Gidesa (2016) reported that Fusarium wilt of hot pepper as a major fungal disease of the crop around studied locations with a magnitude percentage disease severity index of 31.48. In the similar manner the findings also revealed that Phytophtora root rot, Fusarium wilt, and Powdery mildew were the most common and dominant red pepper diseases with percent severity $37.2 \%, 32.8 \%$,
25.0\%, respectively (Mengist et al., 2019). In one way or another almost all investigations conducted on pepper diseases in Ethiopia indicated different fungal plant pathogens caused the most significant devastating/ destructive diseases despite the lack of wide sense in their studies, restricted in one or less pepper agro ecological zones in the country (Mekonen and Chala, 2014; Assefa et al., 2015; Abebe and Abera, 2019).

Having the awareness and familiarity with the major bottleneck pepper production at national level permits pepper producers to search for the effective alternative management options at least for the economically important diseases across locations. The economic damages of fungal disease to pepper crop is considerable and is very worsening in smallholder farmers who do not have adequate knowledge and information on major diseases that devastate their pepper crop and the management packages to reduce level of yield loss. On the other hand, there was limited information that revealed the extent and geographical distribution of each important foliar and soil borne fungal diseases of pepper across the country. Besides, there is a need to have a complete picture on the importance of the diseases across geographic regions and major pepper agro-ecological zones to identify the hotspot areas of the key fungal diseases and develop feasible management options for urgent intervention to maintain production. Thus, the objectives of the study were to (1) identify and document pepper fungal diseases throughout major pepper growing areas of Ethiopia and (2) map the spatial distribution of economically important fungal disease that affect pepper in the study areas.

\section{MATERIALS AND METHODS}

\section{Description of the study area}

The study was conducted in major pepper growing areas across the country. A total of 133 farmers' fields, 26 districts and 9 zones were surveyed at seedling to fruit setting stages of the crop. The examined zones were purposefully chosen to represent the country's key hot pepper (Capsicum species) farming areas. In each zone at least two districts were selected based on the area cavorage of pepper production. From each woreda 1-5 farmer fields were assessed. During the assessments an agricultural expert and small-scale farmers were interviewed for production of pepper, major constraints, cropping history, cropping system, the methods that 
they used to control different diseases, climate conditions such as relative humidity (\%), temperatures $\left({ }^{\circ} \mathrm{C}\right)$ and major vegetation covers (availability of pepper crop). The altitude in which the investigation conducted as general was ranged from 1435-2278 meters above sea level (m.a.s.l.). Global positioning system (GPS) was used to record altitude, latitude and longitude for mapping of the geographical distribution of diseases. The disease maps were utilized to explore outbreak trends over the study period by depicting magnitude, percent disease index, and occurrence levels throughout pepper agro-ecologies (zones and districts).

\section{Sampling procedures}

The diagnosis of major diseases on pepper in major growing agro-ecological zones across the country carried out during the main and/or off-season of the 2018 and 2019/20 cropping seasons. Districts were surveyed based on production of pepper at intervals of 4 to10 km. From each representative zone of major growing areas, sampling points were marked with a global positioning system (GPS) to altitude and coordinates. An ' $\mathrm{X}$ ' fashion sampling technique, in which five spots were made in each farmer's field using $3 \mathrm{~m}$ $\mathrm{x} 3 \mathrm{~m}$ quadrat was implemented. The number of diseased plants and the total number of plants in each quadrat were recorded and data collected from five spots were averaged to represent a site.

\section{Diseases assessment}

Disease prevalence was determined by dividing the number of fields affected by the total number of fields evaluated and presented the percentage result.

$$
\text { Prevalence }(\%)=\frac{\text { No. of infected fields }}{\text { Total no. of fields assessed }} \times 100
$$

Nine fungal diseases causing pathogens were identified in samples collected from six pepper agro-ecological zones in three administrative regions of Oromia, Southern Nations, Nationalities and Peoples (SNNP) and Amhara. Disease incidence was determined by counting the number of healthy and diseased plants at each point within a quadrant and expressed as a percentage of the total number of plants assessed (Mehrotra and Aggarwal, 2003; Mekonen and Chala, 2014).

The number of plants within 10 randomly selected stand showing each disease symptoms were counted and expressed as a percentage of the total number of stands per plot using the following formula (Adedire et al., 2019).
Percent disease incidence (\%)

$$
=\frac{\text { No. of plants wilted }}{\text { Total No. of plants observed }} \times 100
$$

\section{Systemic diseases}

The severity of wilt was calculated by ranking ten plants from each quadrat using 0-6 disease scoring key (Wongpia and Lomthaisong, 2010; Ferniah et al., 2014); where, $0=$ no disease observed, $1=$ slight stunting, $2=$ slight stunting and chlorosis of leaves, $3=<10 \%$ of the leaves showing chlorosis and/or $10 \%$ of the plants with wilt symptoms, $4=<11-25 \%$ of the plant with wilt symptoms, $5=26-50 \%$ of the plant with wilt symptoms, $6=51-100 \%$ of the plant with wilt symptoms or plant death. On the other hand, the intensity of infection for Phytophthora capsici was recorded as $1=$ no visible symptom; 2 = lower leaves wilted, with slight constriction of the stem; 3 = all leaves wilted, with slight discoloration of the stem; $4=$ all leaves were wilted and had rotted collar with visible sporulation on the stem surface; and $5=$ wilting and death of the whole plant, using a 1-5 scale (Yandoc-Ables et al., 2007). Every randomly sampled severity scores were converted to percentage severity index, or PSI as suggested by Baker and Wheeler (1970):

PSI (\%)

$=\frac{\text { Sum of numerical ratings per quadrat }}{\text { Total no. of plants observed } \mathrm{x} \text { maximum score on scale }} \times 100$

A practical guide to the identification of pepper diseases was used to investigate the diagnosis of pepper diseases based on disease symptoms in the farmers' field (Shankar et al., 2014). Potato Dextrose Agar (PDA) medium was used to isolate most fungal plant pathogens while Phytophthora capsici was identified following the procedure developed by Brasier and Susan (2004) with the modification of using homemade (fresh artificial prepared at laboratory) Carrot agar medium. Following the isolation procedures, segments of root/stem/leaves samples with lesions characteristic of suspected diseases were thoroughly washed under running tap water, cut into small pieces $(2 \mathrm{~mm} \times 2 \mathrm{~mm}$ size) with half healthy and half diseased tissue, and surface sterilized with a $70 \%$ ethanol for 30 to 60 seconds based on the surface roughness before being washed three times in sterile distilled water. Samples were dried on filter paper before being placed to potato 
dextrose agar (PDA) plates $(9 \mathrm{~cm}$ diameter) then treated with streptomycin $(30 \mathrm{~g} / \mathrm{l})$ to avoid bacterial contamination, and incubated at $25 \pm 2^{\circ} \mathrm{C}$ in incubator (Arnold et al., 2003; Agrios, 2005).

In addition, microscopic identification in laboratory was done using standard procedures for biotrophics fungal plant pathogens using Key in the manual of illustrated genera of imperfect fungi (Barnett and Hunter, 1972) available in mycology laboratory of Ambo Agricultural Research Centre. Koch's postulate approach was followed to confirm the presence of pathogenic fungi. The isolated and purified conidia were harvested into a $15 \mathrm{ml}$ beaker from 10-day old cultures by adding $10 \mathrm{ml}$ of sterile distilled water (SDW) to each Petri plate. To remove mycelial masses, the suspension was filtered through sterile cheese cloth. Conidia were resuspended in SDW from the filtered culture, and the final conidial density was adjusted to $1 \times 10^{6}$ spore $/ \mathrm{ml}$ using a haemocytometer. The usual cut-root dip inoculation approach for vascular wilt diseases was used for inoculation (Herman and Perl-Treves, 2007; Karimi et al., 2010).

\section{Data analysis}

Disease data, prevalence, incidence and present severity index, were analysed using descriptive statistics of SAS program, version $9.4 \AA$ procedures (SAS, 2015). By interpolating the surface from GPS points, disease distribution maps were generated using the Arc GIS 10.3 program with spatial analyst and the associated field severity data using the inverse distance weighted (IDW) interpolation method.

\section{RESULTS}

Prominence of major fungal diseases of pepper in 2018 and 2019/20 main growing seasons

Among 133 fields assessed, Cercospora leaf spot caused by Cercospora capsici was prevalent in $39.8 \%$ fields. This was followed by Fusarium wilt caused by Fusarium oxysporum f.sp. capsici, and Phytophthora collar, root and fruit rot caused by Phytophthora capsici, prevalent in $21.1 \%$ and $15.8 \%$ fields, respectively (Figure 1 and Table 1 ).

Table 1. Overall mean prevalence, incidence and severity of pepper fungal diseases in the 2018 and 2019/20 main growing seasons.

\begin{tabular}{|c|c|c|c|c|c|c|c|c|c|c|}
\hline Disease & $\mathrm{NZ}$ & $\begin{array}{l}\text { Altitude } \\
\text { (m.a.s.l) }\end{array}$ & $\begin{array}{l}\text { Temp } \\
\left({ }^{\circ} \mathrm{C}\right)\end{array}$ & $\mathrm{RH}(\%)$ & NIF & $\begin{array}{l}\text { OMP } \\
(\%)\end{array}$ & $\begin{array}{l}\text { OMI } \\
(\%)\end{array}$ & SD & $\begin{array}{l}\text { OM PSI } \\
(\%)\end{array}$ & SD. \\
\hline $\begin{array}{l}\text { Fusarium wilt (Fusarium } \\
\text { oxysporum f.sp. capsici) }\end{array}$ & 9 & $1553-2278$ & $16.3-40.2$ & $22-86$ & 28 & $\begin{array}{l}21.0 \\
5\end{array}$ & $\begin{array}{l}55 . \\
4\end{array}$ & 20.3 & & \\
\hline $\begin{array}{l}\text { Fusarium stem and root } \\
\text { rot (Fusarium solani) }\end{array}$ & 9 & $1554-2057$ & $20.4-40.2$ & $22-76$ & 20 & 15 & $\begin{array}{l}69 . \\
5\end{array}$ & 23 & & \\
\hline $\begin{array}{l}\text { Phytophthora blight } \\
\text { (Phytophthora capsici) }\end{array}$ & 9 & $1553-2045$ & $16.3-36.9$ & $27-68$ & 21 & 15.8 & $\begin{array}{l}33 . \\
1\end{array}$ & 18.1 & & \\
\hline $\begin{array}{l}\text { Cercospora leaf spot } \\
\text { (Cercospora capsici) }\end{array}$ & 9 & $1435-2134$ & $20-68$ & $20-68$ & 53 & 39.8 & $\begin{array}{l}39 . \\
4\end{array}$ & 25.5 & 7.9 & 11.9 \\
\hline $\begin{array}{l}\text { Anthracnose } \\
\text { (Colletotrichum spp.) }\end{array}$ & 9 & $1553-1830$ & $22.7-36.9$ & $29-76$ & 5 & 3.76 & 66 & 24 & 30 & 15 \\
\hline $\begin{array}{l}\text { Verticillium wilt } \\
\text { (Verticillium dahliae) }\end{array}$ & 9 & $1612-1905$ & $28.9-33.5$ & $34-47$ & 3 & 2.3 & $\begin{array}{l}43 . \\
3\end{array}$ & 23.1 & & \\
\hline $\begin{array}{l}\text { Damping off (Pythium } \\
\text { spp. and Rhizoctonia } \\
\text { solani) }\end{array}$ & 9 & $1688-2052$ & $16.3-36.9$ & $29-86$ & 6 & 4.5 & $\begin{array}{l}56 . \\
7\end{array}$ & 36.1 & & \\
\hline $\begin{array}{l}\text { Powdery mildew } \\
\text { (Leveillula taurica) }\end{array}$ & 9 & $1553-1905$ & $16.3-26.9$ & $27-68$ & 2 & 1.5 & $\begin{array}{l}46 . \\
7\end{array}$ & 25.5 & & \\
\hline
\end{tabular}

$\mathrm{NZ}=$ number of zones; $\mathrm{SD}=$ standard deviation; NIF = number of infected fields; OMP = overall mean prevalence; $\mathrm{OMI}=$ overall mean incidence; and OMPDI = overall mean percent severity index.

Note that: incidence =Percent severity index for Fusarium wilt (Fusarium oxysporum f.sp. capsici), Fusarium stem and root rot (Fusarium solani) and Phytophthora blight (Phytophthora capsici) 
Overall maximum mean disease incidence of $69.5 \%$ was recorded for Fusarium stem and root rot caused by Fusarium solani followed by Anthracnose (66\%), damping off $(56.7 \%)$ caused by (Pythium spp., and Rhizoctonia solani), Fusarium wilt (55.4\%) caused by Fusarium oxysporum f.sp. capsici and Powdery mildew (46.7\%) caused by Leveillula taurica, in that order (Figure 1 and Table 1). The highest overall mean severities recorded were $30 \%$ and $7.9 \%$, for Anthracnose and Cercospora leaf spot, respectively. Similarly, the most common and prevalent diseases of red pepper were Phytophthora root rot, Fusarium wilt, Powdery mildew, Anthracnose, Cercospora leaf spot, and Downy mildew (Dessie et al.,
2019). Based on the current results, most of the diseases recorded were fungal soil-borne causing pathogens. Moreover, the outbreak of some diseases was observed. For instance, Fusarium stem and root rot caused by Fusarium solani, Phytophthora collar, root and fruit rot caused by Phytophthora capsici were among economically important diseases of pepper detected in major growing areas across the country at the study period. This might be due to the fluctuation of environmental conditions that affect the development of plant diseases and shifted the diseases from minor to major in one country or locality. These might include temperature, relative humidity, soil moisture, soil $\mathrm{pH}$, soil type, and soil fertility.

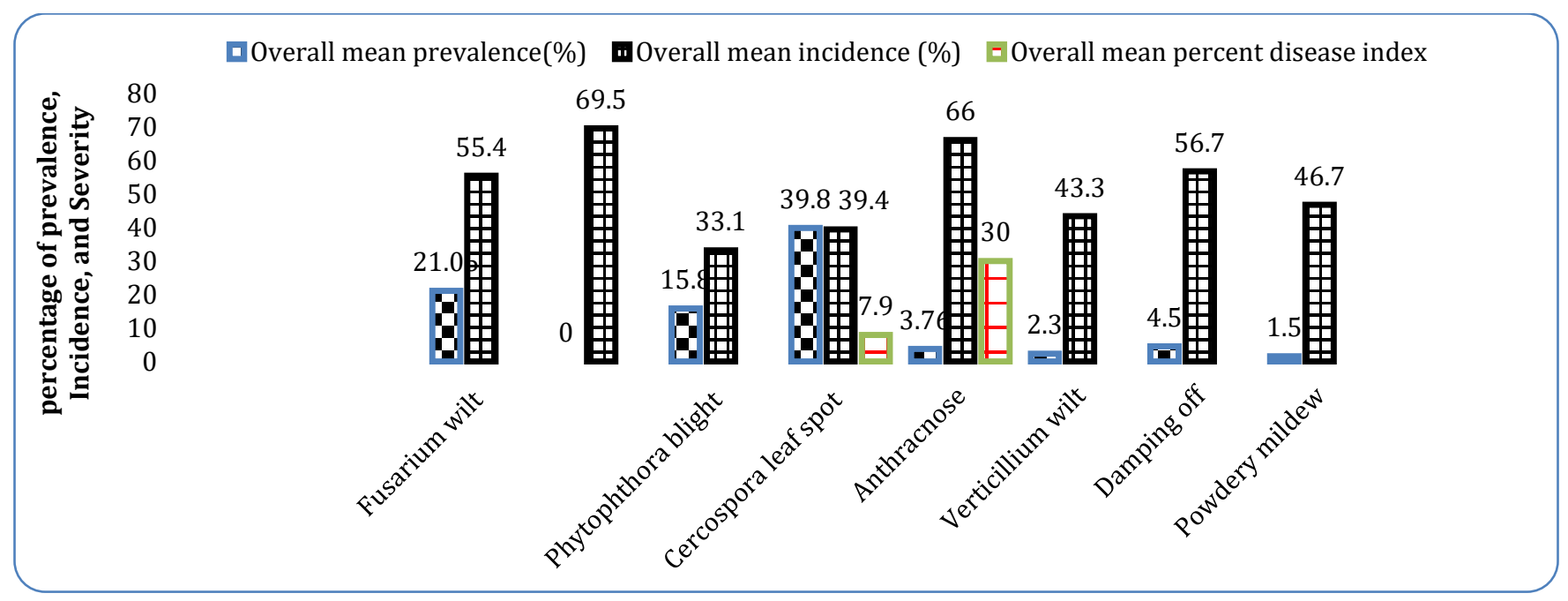

Figure 1: Major fungal diseases identified from samples of Capsicum species during 2018 and $2019 / 20$ main growing season in Ethiopia.

\section{Status of major fungal diseases}

Fusarium oxysporum f.sp capsici wilt (FOCW) recorded maximum mean intensity (Percent severity index) that ranged from $40-100 \%$ in Nono and Ilu Galan districts of West Shewa zone as well as Sibu sire district of East Wollega zone, followed by $30-80 \%$ range in Bure district of West Gojjam. Relatively, FOCW pathogen was the most prevalent and observed to cause economic damage in Nono, Ilu Galan and Sibu sire districts of West Shewa and East Wollega zones (Table 2).

Fusarium solani symptoms such as soft, dark brown or chlorotic lesion were formed on the stem, usually at nodes or wound sites. These might girdle the stem in later stages of disease development. There was also a dark brown discoloration of the internal portion of the stem that may extend to a considerable distance (Figure $3 \mathrm{~A}$ and $\mathrm{B}$ ). The highest up to $100 \%$ incidence of Fusarium stem and root rot recorded in Nono, Abeshge, Marako and Bure and districts at which the altitude ranged from 1553-1858 m.a.s.l. The disease intensity also progressed with the temperature in the range of $22-40.2^{\circ} \mathrm{C}$ (Table 2).

Phytophthora capsici intensity of $100 \%$ recorded in Nono, followed by $70 \%, 50 \%$ and $42.5 \%$ for Weyra, Wenberma and Bako tibe districts, respectively. It was also noticed that this disease became important on pepper in major pepper producing agro-ecological zones in Ethiopia (Table 2). In line with the current study Mengist et al. (2019) reported that Phytophtora root rot (37.2\%), Fusarium wilt (32.8\%), and Powdery mildew $(25.0 \%)$ were the most prevalent red pepper diseases in all investigated areas, while Cercospora leaf spot had the least (14.5\%) severity. In addition in this study the severity of Cercospora leaf spot caused by Cercospora capsici also ranged in between 1-80\% (Table 3). 
Table 2: Mean incidence of Fusarium oxysporum f.sp capsici, Fusarium solani and Phytophthora capsici across surveyed areas in the main growing season (2018 and 2019/20).

\begin{tabular}{|c|c|c|c|c|c|c|c|c|c|c|c|}
\hline \multicolumn{12}{|c|}{ Fusarium oxysporum f.sp capsici } \\
\hline \multirow{2}{*}{ Zones } & \multirow{2}{*}{ Districts } & \multirow{2}{*}{ NIF } & \multirow{2}{*}{$\begin{array}{l}\text { Altitude range } \\
\text { (m.a.s.l) }\end{array}$} & \multicolumn{2}{|c|}{ Temp $\left({ }^{\circ} \mathrm{C}\right)$} & \multicolumn{2}{|c|}{ RH\% } & \multirow{2}{*}{\multicolumn{2}{|c|}{ DI $(\%)$}} & \multirow{2}{*}{$\begin{array}{l}\text { SD } \\
\pm\end{array}$} & \multirow{2}{*}{$\mathrm{CV}(\%)$} \\
\hline & & & & Min & Max & Min & Max & & & & \\
\hline \multirow{2}{*}{ West Shewa } & Ilu Galan & 4 & $1648-1750$ & 26 & 31.1 & 40 & 78 & 62.5 & $40-100$ & 26.3 & 42.1 \\
\hline & Nono & 1 & 1554 & 32 & 32 & 45 & 45 & 100 & 100 & & \\
\hline East Wollega & Sibu sire & 2 & 1768-1782 & 28 & 31 & 41 & 59 & 70 & $40-100$ & 24.8 & 35.4 \\
\hline \multirow{2}{*}{ Jimma } & Omonada & 1 & 1553 & 26.1 & 31.1 & 42 & 57 & 60 & 60 & & \\
\hline & Kersa & 1 & 1750 & 29.4 & 29.4 & 46 & 48 & 60 & 60 & & \\
\hline \multirow{2}{*}{ Gurage } & Abeshge & 3 & $1609-1805$ & 20.4 & 27.7 & 52 & 76 & 53.3 & $40-60$ & 9.4 & 17.7 \\
\hline & Marako & 1 & 1821 & 30.5 & 30.7 & 51 & 53 & 60 & 60 & & \\
\hline Halaba & Abote Wulu & 2 & $1873-1905$ & 16.3 & 36.9 & 29 & 86 & 35 & $20-50$ & 21.2 & 60 \\
\hline \multirow{4}{*}{ West Gojjam } & Bure & 5 & $1658-2278$ & 25 & 40.2 & 22 & 62 & 52 & $30-80$ & 21.67 & 41.7 \\
\hline & Finoteselam & 2 & 1996-2007 & 30.7 & 33.3 & 31 & 55 & 50 & $40-60$ & 14.1 & 28.3 \\
\hline & Wenberma & 4 & 2024-2068 & 29.6 & 32.3 & 36 & 53 & 52 & $40-60$ & 9.6 & 18.2 \\
\hline & Jabi Tehnan & 2 & $1794-1815$ & 30 & 32.8 & 41 & 46 & 40 & 40 & 0 & 0 \\
\hline \multicolumn{12}{|c|}{ Fusarium solani } \\
\hline \multirow{2}{*}{ West shewa } & Dano & 1 & 1727 & 27 & 28.7 & 50 & 68 & 60 & 60 & & \\
\hline & Nono & 2 & $1554-1858$ & 22 & 37 & 29 & 76 & 85 & $70-100$ & 5.7 & 6.7 \\
\hline \multirow[t]{2}{*}{ East wollega } & Sibu sire & 3 & $1757-1846$ & 29.1 & 38.6 & 28 & 51 & 43.3 & $40-50$ & 5.8 & 13.3 \\
\hline & Abeshge & 3 & $1553-1805$ & 20.4 & 30.2 & 47 & 76 & 86.7 & $70-100$ & 15.3 & 17.6 \\
\hline \multirow[t]{2}{*}{ Gurage } & Kebena & 1 & 1786 & 23.3 & 24 & 64 & 66 & 100 & 100 & & \\
\hline & Marako & 2 & $1815-1830$ & 30.5 & 38.3 & 29 & 50 & 80 & $60-100$ & 28.3 & 35.4 \\
\hline \multirow[t]{2}{*}{ Halaba } & Weyra dujo & 1 & 2045 & 26.3 & 30.9 & 37 & 61 & 50 & 50 & & \\
\hline & Bure & 5 & $1983-2025$ & 32.1 & 40.2 & 22 & 52 & 68 & $40-100$ & 27.7 & 40.8 \\
\hline \multirow[t]{2}{*}{ West Gojjam } & Wenberma & 1 & 2057 & 31.3 & 31.8 & 36 & 49 & 60 & 60 & & \\
\hline & Jabi Tehnan & 1 & 1884 & 29 & 29.2 & 48 & 51 & 60 & 60 & & \\
\hline \multicolumn{12}{|c|}{ Phytophthora capsici } \\
\hline \multirow{3}{*}{ West shewa } & Bako Tibe & 2 & $1647-1690$ & 32.7 & 36.9 & 29 & 47 & 42.5 & $40-45$ & 3.5 & 8.3 \\
\hline & Ilu galan & 5 & $1648-1750$ & 26 & 36.9 & 29 & 78 & 30 & $10-60$ & 21.2 & 70 \\
\hline & Nono & 1 & 1554 & 32 & 32 & 45 & 45 & 100 & 100 & & \\
\hline S/W/Shewa & Goro & 1 & 1764 & 22.5 & 23.3 & 66 & 78 & 40 & 40 & & \\
\hline East Wollega & Sibu sire & 1 & 1782 & 28 & 30 & 47 & 59 & 40 & 40 & & \\
\hline Jimma & Omonada & 3 & $1553-1770$ & 26.1 & 31.1 & 42 & 58 & 23.3 & $10-40$ & 15.3 & 65.5 \\
\hline Gurage & Abeshge & 2 & $1765-1805$ & 20.4 & 24.4 & 64 & 76 & 40 & $30-50$ & & \\
\hline
\end{tabular}




\begin{tabular}{|c|c|c|c|c|c|c|c|c|c|c|c|}
\hline \multirow{2}{*}{ Halaba } & Weyra dujo & 1 & 2045 & 26.3 & 30.9 & 37 & 61 & 26.3 & 20 & & \\
\hline & Weyra & 1 & 1881 & 16.3 & 36.9 & 29 & 86 & 70 & 70 & & \\
\hline \multirow{3}{*}{ West Gojjam } & Bure & 2 & 1658-1999 & 25.8 & 36.1 & 27 & 62 & 30 & $10-50$ & 28.3 & 94 \\
\hline & Wenberma & 1 & 2042 & 29.5 & 29.8 & 44 & 44 & 50 & 50 & & \\
\hline & Jabi Tehnan & 2 & $1600-1794$ & 17.7 & 33.8 & 33 & 82 & 15 & $10-20$ & & \\
\hline
\end{tabular}

Table 3: Mean incidence and severity of Cercospora leaf spot/Frogeye on Capsicum across surveyed areas.

\begin{tabular}{|c|c|c|c|c|c|c|c|c|c|c|c|}
\hline \multirow{3}{*}{ Zones } & \multicolumn{11}{|c|}{ Cercospora leaf spot (Cercospora capsici) } \\
\hline & \multirow{2}{*}{ Districts } & \multirow{2}{*}{ NIF } & \multirow{2}{*}{$\begin{array}{l}\text { Altitude range } \\
\text { (m.a.s.l) }\end{array}$} & \multicolumn{2}{|c|}{ Temp $\left({ }^{\circ} \mathrm{C}\right)$} & \multicolumn{2}{|c|}{$\underline{\mathrm{RH} \%}$} & \multicolumn{2}{|c|}{ DI (\%) } & \multicolumn{2}{|c|}{ Severity (\%) } \\
\hline & & & & Min & Max & Min & Max & Mean & Range & Mean & Range \\
\hline \multirow{2}{*}{ West shewa } & Ilu Galan & 6 & $1648-1729$ & 26 & 31.1 & 29 & 78 & 81.67 & $60-100$ & 23.3 & $10-80$ \\
\hline & Dano & 1 & 1727 & 27 & 28.7 & 50 & 68 & 60 & 60 & 10 & 10 \\
\hline S/W/shewa & Goro & 1 & 1764 & 22.5 & 23.3 & 66 & 78 & 50 & 50 & 10 & 10 \\
\hline \multirow[t]{2}{*}{ East Wollega } & Sibu sire & 6 & $1757-1846$ & 28 & 38.6 & 41 & 28 & 21.67 & $10-30$ & 3 & $1-5$ \\
\hline & Omonada & 6 & 1553-1795 & 26.1 & 31.1 & 38 & 61 & 28.33 & $20-50$ & 2 & $1-5$ \\
\hline \multirow[t]{2}{*}{ Jimma } & Kersa & 2 & $1740-1750$ & 31.1 & 31.4 & 38 & 42 & 30 & $10-50$ & 5.5 & $1-10$ \\
\hline & Around Jimma & 1 & 1734 & 31.4 & 31.4 & 38 & 39 & 60 & 60 & 12 & 12 \\
\hline Kefa & Gimbo & 3 & $1435-1787$ & 32 & 39.7 & 23 & 40 & 25 & $10-20$ & 1 & 1 \\
\hline \multirow[t]{2}{*}{ Gurage } & Abeshge & 2 & $1765-1805$ & 20.4 & 24.4 & 64 & 76 & 45 & $40-50$ & 7.5 & $5-10$ \\
\hline & Atote Wulu & 2 & 1873-1905 & 16.3 & 36.9 & 29 & 86 & 65 & $60-70$ & 15 & $10-20$ \\
\hline \multirow[t]{3}{*}{ Halaba } & Weyra & 2 & $1814-1881$ & 16.3 & 36.9 & 29 & 86 & 100 & $40-100$ & 7.5 & $5-10$ \\
\hline & Bashano & 1 & 2056 & 27.3 & 30.9 & 37 & 61 & 50 & 50 & 10 & 10 \\
\hline & Bure & 8 & $1658-2134$ & 29 & 41.9 & 20 & 62 & 27.5 & $20-60$ & 2.75 & $1-10$ \\
\hline \multirow{3}{*}{ West Gojjam } & Finoteselam & 3 & $1996-2027$ & 30.7 & 33.3 & 31 & 55 & 56.67 & $20-90$ & 18.3 & $1-30$ \\
\hline & Wenberma & 5 & 2024-2068 & 29.5 & 32.5 & 39 & 53 & 28 & $10-50$ & 8.4 & $1-20$ \\
\hline & Jabi Tehnan & 3 & $1600-2027$ & 17.7 & 33.8 & 33 & 82 & 20 & $10-30$ & 4 & $1-5$ \\
\hline
\end{tabular}

RH, relative humidity; NIF,Number of infected field; DI, Disease incidence ;Temp, Temperature

\section{Symptoms and Morphological characteristics Fusarium oxysporum f.sp capsici wilt (FOCW)}

Disease symptoms were first noted as a slight yellowing of foliage and wilting of upper leaves. As wilting progresses, leaves may turn dull green to brown and remain attached to the plant (Figure
2). When the stem and roots were cut diagonally, reddish brown streaks are visible in the vascular tissues. Characteristics of the pathogen on potato dextrose agar (PDA) medium usually varied, it was produced a pale to dark violet or dark magenta pigment in the agar, but some isolates produced white to pale violet pigment. Macroconidia was short to medium length, straight to slightly curved, relatively slender and thin walled. Apical cell was tapered and with a slight hook. Basal cell was foot shaped to pointed and also had usually 3-septate (Figure 2E and F). 

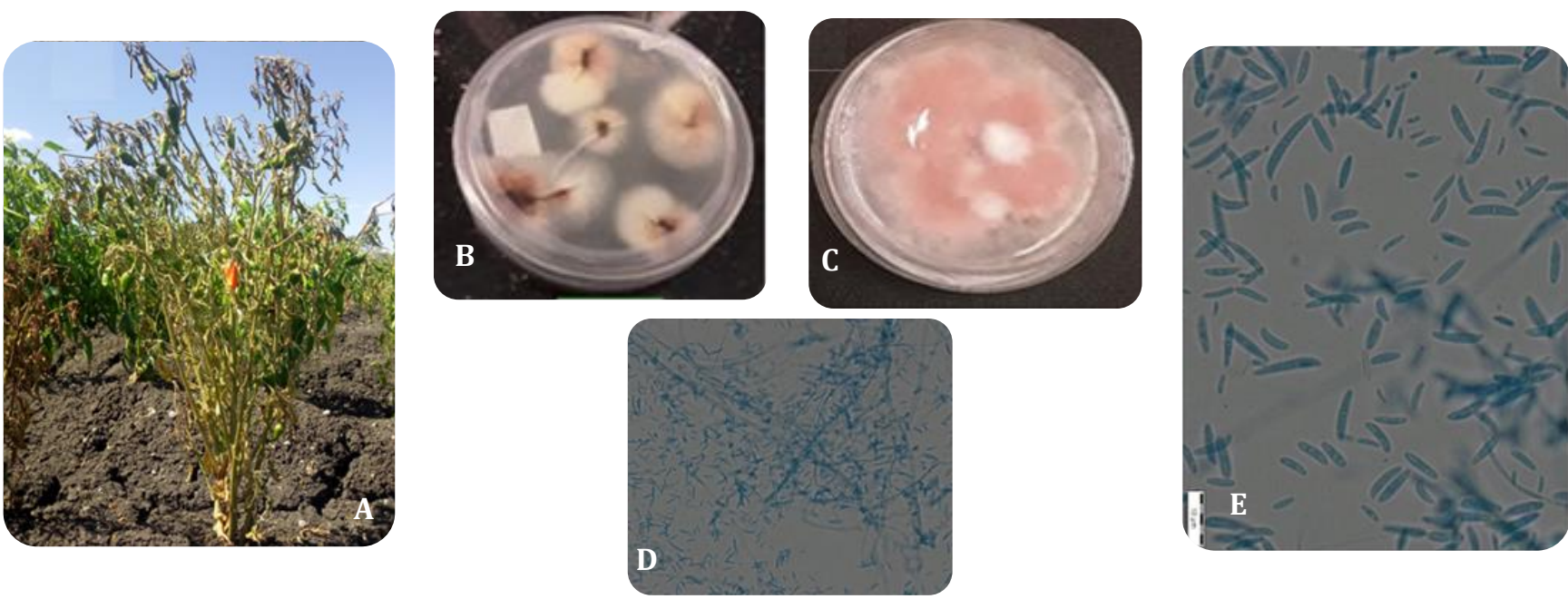

Figure 2: Fusarium oxysporum f.sp. capsici on Capsicum species: typical symptom on plant (A), colony Color on Potato dextrose agar (PDA) medium, macro and micro conidia (B to E).
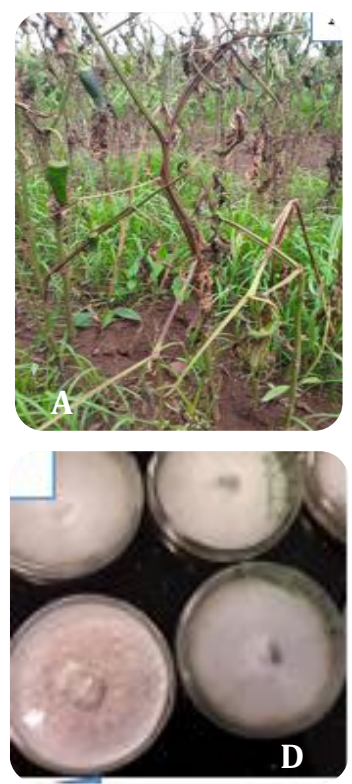
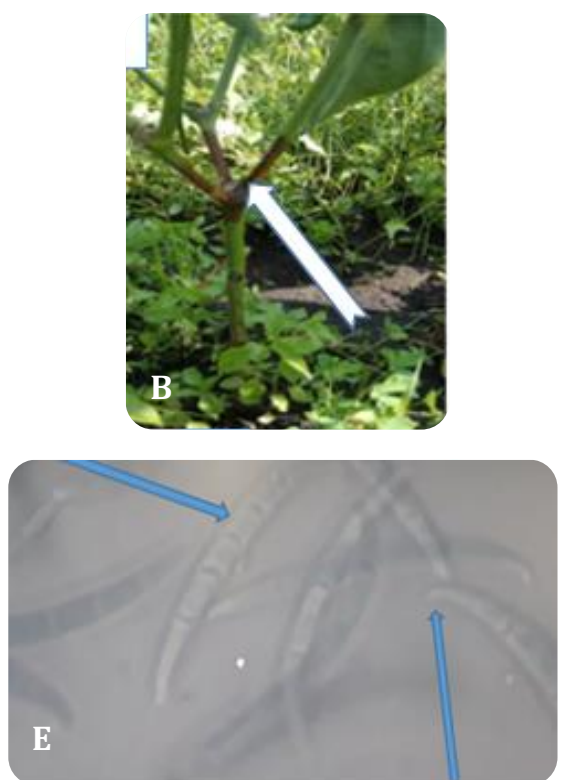
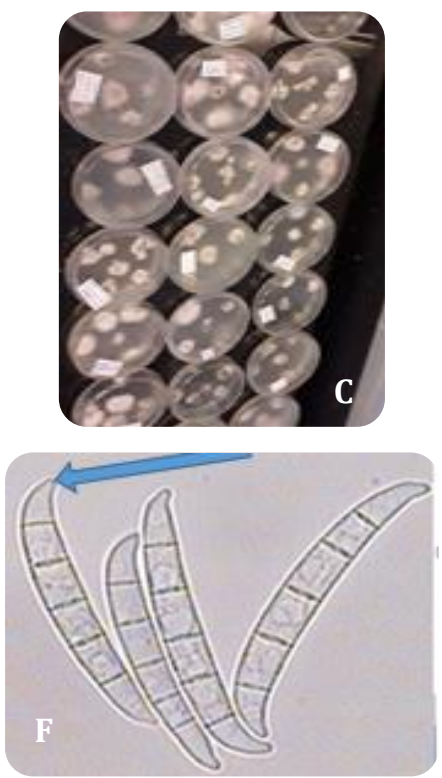

Figure 3: Fusarium stem and root rot caused by Fusarium solani on Capsicum species: infected field (A), typical symptom on plant (A \& B), colony Color on Potato dextrose agar (PDA) medium and macroconidia (E\&F).

Symptomology and Morphological characterization (i.e., microscopic and colony on culture medium) of the pathogen were done in accordance with the (Leslie and Summerell, 2008; Anjos et al., 2019).

\section{Phytophthora capsici}

Wilting is the most common symptom of Phytophthora capsici, followed by root and collar rot, and a dark brown stem lesion that extends upward from the soil line (Figure 5). Phytophthora capsici is also one of the most economically devastating soil-borne pepper diseases throughout the world. The highest (100\%) disease intensity in the current study observed at the altitude of 1554 m.a.s.l., while relatively the minimum (15\%) disease intensity observed at an altitude of 1794 m.a.s.l. This indicated that the disease pressure was higher in the low to mid altitude than high altitude areas. Temperature between $20.4^{\circ} \mathrm{C}$ and $36.9^{\circ} \mathrm{C}$ and relative humidity ranged from 27 to $86 \%$ also favored the disease development (Table 2, Figure 5).

\section{Spatial distribution of diseases in major pepper}




\section{agro-ecological zones}

The findings revealed that the importance and severity of fungal diseases that affect pepper varies depending on the physical environment in the investigated areas.

In this study, FOCW percent incidence ranged from 20$100 \%$ and found up to $100 \%$ in the majority of districts during the study periods. The mean incidence that ranged from $40-100 \%$ recorded in Ilu Galan, Nono and
Dano districts of West Shewa zone, Oromia region. This was followed by West Gojjam zone in which the most infested districts were Bure, Finoteselam, Wemberma and Jabi Tehinan. These districts recorded the mean intensity of FOCW in between 30 and $80 \%$ range. In Gurage zone of SNNP, the intensity ranged from 20-60\% and the most infected areas were Abeshge, Kebena, Marako districts.

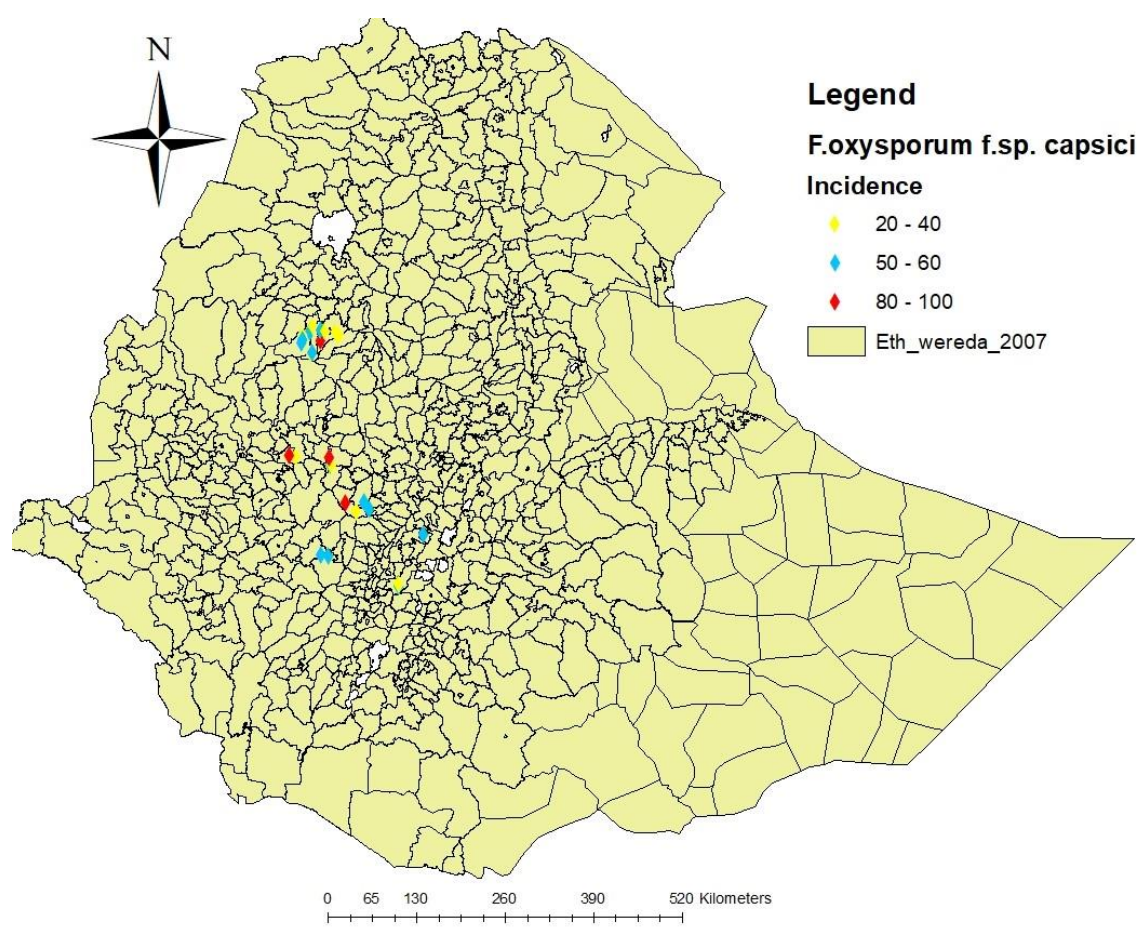

Figure 4: Distribution of Fusarium wilt caused by F. oxysporum f.sp.capsici of Capsicum species on surveyed areas across Ethiopia.

In the current study, relatively low FOCW mean intensity noticed in Halaba special zone which categorized in the range of $20-40 \%$, and Abote Wulu and Weyra dujo were the most infected pepper agro-ecological districts (Figure 4 and Table 2). Fusarium oxysporum f. sp capsici prevalence was mostly observed at intermediate levels (43 to 54\%) in surveyed fields of the Halaba, Mareko, Meskan, and Adama districts (Gabrekiristos et al., 2020). They also stated that mean disease incidence in Adama, Halaba, Meskan and Mareko districts were relatively higher. Moreover, within the same districts, FOCW diseases intensity and pressure progressed in the current study. This showed that the amount of inoculum of FOC in the soil increased rapidly from time to time. At the study period, this disease together with other soilborne diseases made the pepper out of production around this vicinity.

On the other hand, Perscent severity index (PSI) for Fusarium stem and root rot (Fusarium solani) varied from $40 \%$ to $100 \%$. Hence, districts such as Wemberma and Jabi Tehinan of West Gojjam, Kebena and Marako of Gurage zone and Nono and Dano of West Shewa zone were recorded high disease intensity (60\% to $100 \%$ ) compared to other districts which were below $60 \%$ (Figure 6 and Table 2).

Mean intensity of P. capsici also varied from $10-70 \%$ and it was important in West Gojjam zone (Bure, Wemberma and Jabi Tehnan districts), Gurage zone (Abeshge district), Halaba special zone (Weyra dujo district), West Shewa zone (Bako tibe, Nono and Ilu Galan districts), Jimma zone (Omonada district) and East Wollega zone (Sibu sire district) with different level of disease 
intensity (Figure 7). Unlike Fusarium, this disease recorded in Goro district of South West Shewa zone. Root rot disease, caused by Phytophthora capsici, has become a serious threat to pepper production and causes up to $100 \%$ yield losses in commercial vegetable fields (Babadoost, 2004; Babadoost and Islam, 2003; Hausbeck and Lamour, 2004) and is of great importance in different parts of the world including Ethiopia (Mekonen and Chala, 2014; Assefa et al., 2015; Mengist et al., 2019).
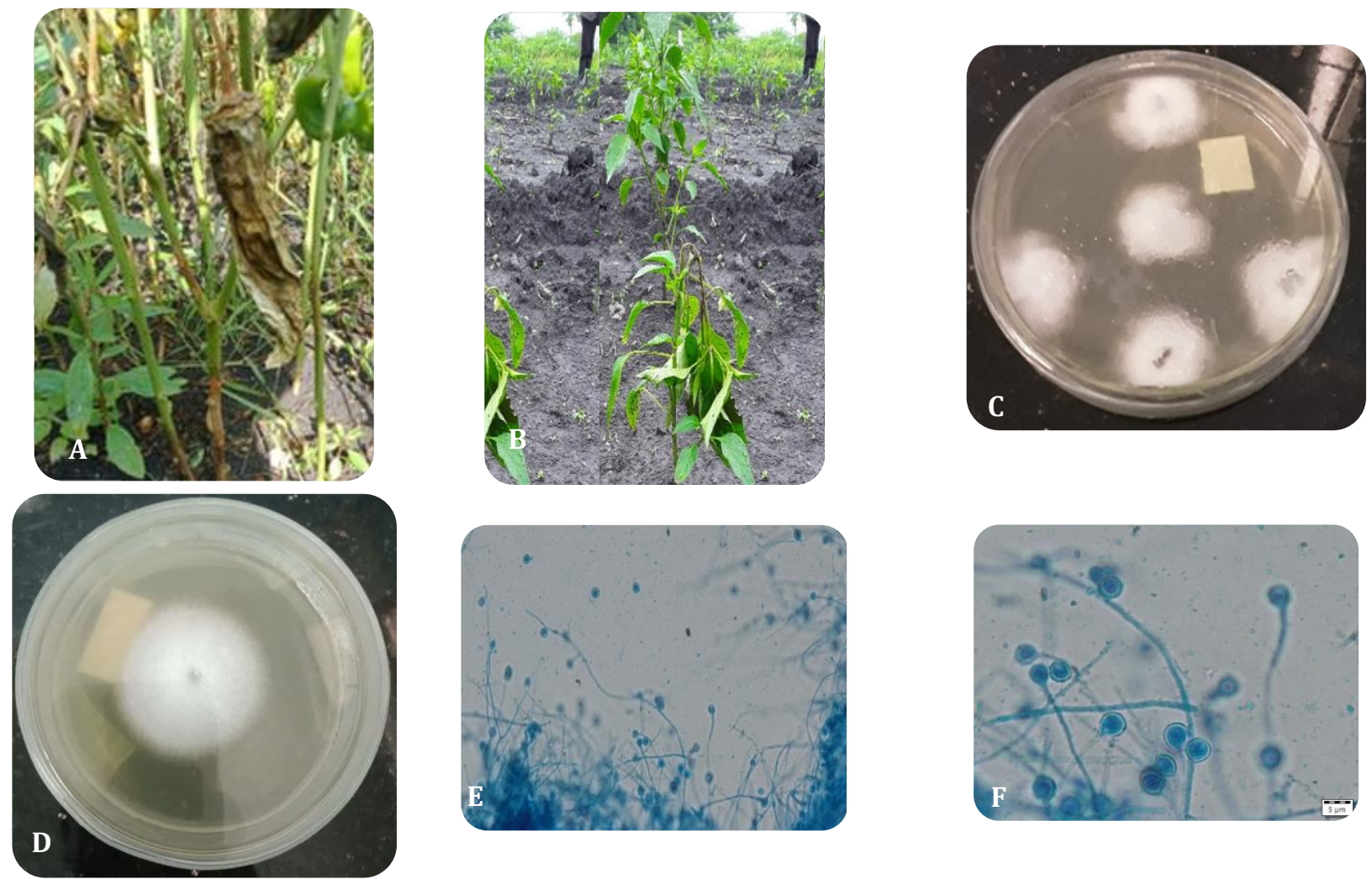

Figure 5: Symptoms caused by Phytophthora capsici (A and B), colony morphology grown for seven days on Carrot agar medium (C and D); morphology of mycelial and sporangium formation (E \& F); zoosporangia (different shape)

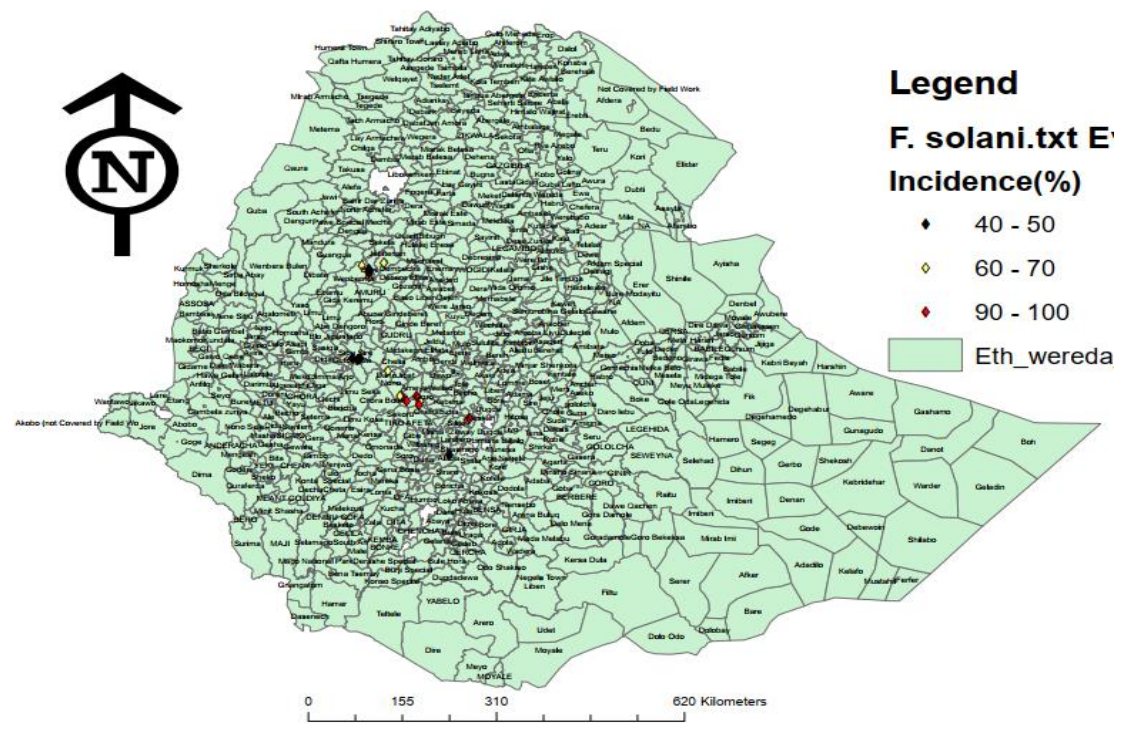

Figure 6: Ethiopia map showing spatial distribution of Fusarium stem and root rot caused by Fusarium solani of pepper on surveyed areas. 


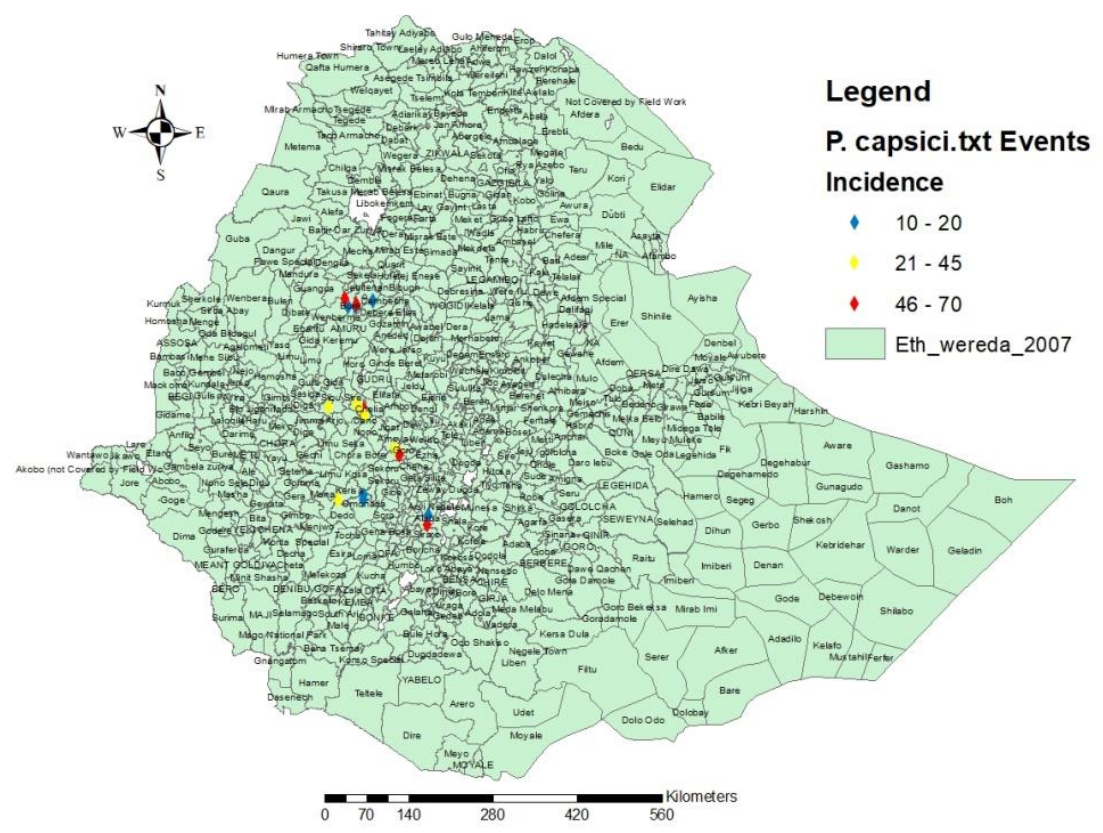

Figure 7: Map of Ethiopia showing geographical distribution of root, collar and fruit rot caused by Phytophthora capsici of Capsicum species on surveyed areas.

\section{DISCUSSION}

There was inadequate information that revealed the extent and spatial distribution of each important fungal disease of pepper across the country. Hence, this investigation updated the information concerning the fungal diseases of Capsicum species in the country and contributed pertinent scientific report to the researchers and beneficiaries in Ethiopian in particular and in the world as general. Accordingly, nine pepper pathogenic fungi were detected in samples collected from different pepper growing areas. Thus, the most prevalent pathogen was Cercospora capsici followed by Fusarium oxysporum f.sp. capsici, and Phytophthora capsici. Overall maximum mean disease incidence was recorded for Fusarium solani followed by Pythium spp., Rhizoctonia solani, Fusarium oxysporum f.sp. capsici and Leveillula taurica, respectively. The most common and prevalent diseases of red pepper were Phytophthora root rot, Fusarium wilt, Powdery mildew, Anthracnose, Cercospora leaf spot, and Downy mildew (Mengist et al., 2019).

Gabrekiristos and Demiyo (2020) reported Fusarium oxysporum f.sp capsici dissemination and intensity in Adami Tullu Jiddo Kombolcha, Dugda, Adama, Meskan, Alaba, and Mareko districts, respectively, with 15.1, 30.9, $40.0,42.9,46.0$, and 46.5 percent wilt incidence. The highest pepper Fusarium wilt, $45 \%$ and $32.5 \%$ was recorded for Abeshge district and Halaba special district, respectively, in SNNPR (Mekonen and Chala, 2014).

FOCW prevalence was mostly documented at intermediate levels (43 to 54 percent) in surveyed fields from Halaba, Mareko, Meskan, and Adama districts (Gabrekiristos and Demiyo, 2020). They also stated that mean disease incidence in Adama, Halaba, Meskan and Mareko districts were relatively higher. Moreover, within the same districts, FOCW diseases intensity and pressure progressed in the current study. This showed that the amount of inoculum of FOC in the soil increased rapidly from time to time. At the study period, this disease and other soil-borne diseases phased out pepper production around this vicinity. Root rot disease caused by Phytophthora capsici, has become a serious threat to pepper production and causes up to $100 \%$ yield losses in commercial pepper fields (Babadoost and Islam, 2003; Babadoost, 2004; Hausbeck and Lamour, 2004) and is of great importance in different parts of the world including Ethiopia (Mekonen and Chala, 2014; Assefa et al., 2015; Mengist et al., 2019).

Ismail et al. (2017) reported that vascular wilt of pepper caused by many species of Fusarium, especially Fusarium solani and Fusarium oxysporum are the most important diseases noticed.

The diseases prevalence, incidence, and percent severity index vary from agroecological district to district, zone to zone, as revealed by the current study. Variability in 
disease intensity could be linked to the environmental conditions and soil type of various places, which favoured the development of disease-causing organisms. These might be correlated with fluctuation of biophysical factors in general that create a negative and/or positive impacts on the occurrence of pepper diseases. This was demonstrated by higher water holding capacity of the vertisoil of Nono and Ilu Galan districts in West Shewa zone and Abeshge district in Gurage zone, as well as flooding was observed/noticed as a common event in West Gojjam which favoured the development of Fusarium species in the areas. In line with this, Mengist et al. (2019) stated that variables such as altitude, varieties, seed bed types, planting time and cropping pattern were significantly associated with red pepper disease. Therefore, this information was pertinent for development of environment-friendly, safe and affordable control methods for those more prevalent and major pepper diseases in the surveyed areas because at least hotspot areas were clearly discovered with the level of infection.

Based on the current results, most of the diseases recorded during the study period were fungal soil-borne diseases. Moreover, the outbreak of epidemic for some diseases observed during the study period, for instance Fusarium stem and root rot caused by Fusarium solani, Phytophthora collar, root and fruit rot caused by Phytophthora capsici were among economically important diseases of pepper detected in most growing areas across the country during the study period. This might be due to the fluctuation of environmental conditions that affect plant diseases and shift the diseases from minor to major in the country or locality. These include temperature, relative humidity, soil moisture, soil $\mathrm{pH}$, soil type, and soil fertility.

In line with this study, Mengist et al. (2019) stated that Phytophthora root rot (37.2\%), Fusarium wilt (32.8\%), and Powdery mildew $(25.0 \%)$ were the most prevalent red pepper diseases in all the investigated areas, while Cercospora leaf spot had the least severity (14.5\%). Phytophthora capsici is one of the most economically devastating soil-borne pepper diseases throughout the world. Tucker (1931) described P. capsici as a Phytophthora species and classified it as a host-specific fungus pathogenic to pepper. In the current study, the disease maps were utilized to explore outbreak trends over the study period by depicting magnitude, percent disease index, and occurrence levels throughout pepper agro-ecologies (zones and districts).

The results from the current investigation revealed the importance and spatial distribution of epidemics of each disease; particularly some diseases were occurred or shifted from unimportant to major ones. For instance, Fusarium stem and root rot (Fusarium solani) and Phytophthora collar, root and fruit rot (Phytophthora capsici) became major diseases of pepper in some areas across the country. Both pathogens sometimes showed similar symptoms at field level, but they were clearly identified by laboratory analysis using appropriate media and microscopic examination. Thus, it needs careful diagnosis for proper management option development. The intensity of Fusarium solani and Phytophthora capsici was high between low to mid altitude, particularly in altitude that ranged from 15531858 m.a.s.l, and temperature up to $40.2^{\circ} \mathrm{C}$ preferred for the disease development and caused total failure of the crop due to outbreak of the epidemics. As a result, this information was paramount for knowing the spatial patterns of epidemics (variation in diseases intensity) in some districts, but was also important toward the development of environmentally safe and affordable control methods for pepper diseases to empower producers with resourceful tools across the country.

\section{CONCLUSION AND RECOMMENDATION}

Although pepper (Capsicum species) is among the most economically important vegetable, its production is currently constrained by infectious pathogens, particularly, those causing fungal soil-borne diseases in Ethiopia. A survey was conducted throughout major growing areas of Ethiopia to know the status and distribution of pepper diseases. At least nine major fungal diseases causing pathogens were identified in samples collected from different pepper-producing regions. It was found out that $90 \%$ of farmers interviewed indicated that the major biotic stresses that recently reduced the yield potential of pepper crop were predominantly fungal pathogens causing soil-borne diseases.

The overall mean incidence was recorded for Anthracnose (66\%) while the maximum overall mean PSI (69.5\%) was recorded from Fusarium stem and root rot (Fusarium solani) infected pepper fields followed by damping-off (56.7\%), Fusarium wilt (55.4\%) (Fusarium oxysporum f. sp. capsici) and Powdery mildew (46.7\%) (Leveillula taurica). 
The current results showed that most of the diseases recorded in the study areas were fungal soil-borne diseases, including Fusarium solani and Phytophthora capsici which occurred at an epidemic level in major pepper growing areas. The intensity of both diseases was high in between low to mid altitude, particularly the altitude ranged from 1553-1858 m.a.s.l, and temperature up to $40.2^{\circ} \mathrm{C}$. Yet, previously these diseases were considered as minor problems on pepper production areas. In this study, however, both diseases were recorded as major and geographically distributed in pepper growing areas of Ethiopia. Therefore, based on this results development of environmentally safe, practical, cost effective and sustainable management strategies should be included in the crop production to reduce the economic impact of the diseases. Moreover, molecular characterization for economic diseases; development molecular primers should be prioritized to improve the detection of these major diseases; genome wide evaluation and screening of capsicum species genotypes are environment-friendly, safe and affordable diseases management strategies have been suggested to facilitate sustainable pepper production.

\section{ACKNOWLEDGEMENT}

The authors are grateful for the Ethiopian Institute of Agricultural Research (EIAR) and Korea Program on International Agriculture (KOPIA) project for the financial and logistical supports.

\section{REFERENCES}

AARC. 2019. Progress Report 2018/2019. Ambo Agricultural Research Centre, Plant Protection Research Division, Department of Plant Pathology.

Abebe, A. and M. Abera. 2019. Pepper disease assessment and identification in major growing districts of west Gojam zone in Northwestern Ethiopia. International Journal of Sustainable Agricultural Research, 6: 8-20.

Adedire, O. M., A. Pitan, A. O. Farinu and W. F. Ogundipe. 2019. The biocontrol of soil transmitted Cercospora capsici with Lactobacillus plantarum. Journal of Advances in Microbiology, 18: 1-8.

Agrios, G. N. 2005. Plant Pathology. Academic Press: New York, USA.

Anjos, I. V. d., S. S. d. Melo, T. A. S. Gilio, J. P. Kreitlow, S. M. A. d. S. Neves, K. L. Araújo, M. E. Serafim and L. G. Neves. 2019. Molecular characterization of isolates of Fusarium spp. associated with wilt in Capsicum spp. Journal of Agricultural Science, 11: 519-27.

Arnold, A. E., L. C. Mejia, D. Kyllo, E. I. Rojas, Z. Maynard, N. Robbins and E. A. Herre. 2003. Fungal endophytes limit pathogen damage in a tropical tree Proceedings of the National Academy of Sciences. pp. 15649-54.

Assefa, M., W. Dawit, A. Lencho and T. Hunduma. 2015. Assessment of wilt intensity and identification of causal fungal and bacterial pathogens on hot pepper (Capsicum annuum L.) in Bako Tibbe and Nonno districts of West Shewa zone, Ethiopia. International Journal of Phytopathology, 4: 21-28.

Babadoost, M. 2004. Phytophthora blight: A serious threat to cucurbit industriesAmerican Phytopathological Society. St. Paul, MN, USA.

Babadoost, M. and S. Z. Islam. 2003. Fungicide seed treatment effects on seedling damping-off of pumpkin caused by Phytophthora capsici. Plant disease, 87: 63-68.

Baker, K. F. and B. E. J. Wheeler. 1970. An Introduction to plant diseases. Mycologia, 62: 617-19.

BARC. 2000. Progress Report 1999/2000. Bako Agricultural Research Centre, Crop Protection Research Division.

Barnett, H. L. and B. B. Hunter. 1972. Illustrated Genera of Imperfect Fungi. Burgess Publishing Company: Minneapolis.

Bosland, P. W., E. Votava, J. and E. M. Votava. 2012. Peppers: Vegetable and Spice Capsicums. CAB International: London, UK.

CSA. 2020. Agricultural sample survey 2019/2020 (2012 E.C.): Report on area and production of major crops (Private peasant holdings, Meher season). Central Statistical Agency. Federal Democratic Republic of Ethiopia.

Dessie, A. B., T. M. Abate, T. M. Mekie and Y. M. Liyew. 2019. Crop diversification analysis on red pepper dominated smallholder farming system: Evidence from northwest Ethiopia. Ecological Processes, 8: 1-11.

FAO. 2019. FAO Production Year Book. Food and Agriculture Organization of the United Nations. Rome, Italy.

Gabrekiristos, E. and T. Demiyo. 2020. Hot pepper fusarium wilt (Fusarium oxysporum f. sp. capsici): Epidemics, characteristic features and 
management options. Journal of Agricultural Science, 12: 347-56.

Hausbeck, M. K. and K. H. Lamour. 2004. Phytophthora capsici on vegetable crops: Research progress and management challenges. Plant disease, 88: 1292303.

Herman, R. and R. Perl-Treves. 2007. Characterization and inheritance of a new source of resistance to Fusarium oxysporum f. sp. melonis Race 1.2 in Cucumis melo. Plant disease, 91: 1180-86.

Ismail, M. A., A. Moubasher, A. M. El-Eraky, A. H. El-Shaer and H. A. Gouda. 2017. Virulence of wilt pathogens against pepper cultivars in Egypt. International Journal of Technical Research \& Science, 1: 304-14.

Karimi, E., E. Oskoueian, R. Hendra and H. Z. E. Jaafar. 2010. Evaluation of Crocus sativus L. stigma phenolic and flavonoid compounds and its antioxidant activity. Molecules, 15: 6244-56.

Kebede, M. and A. Gidesa. 2016. Survey and identification of diseases on major crops of Assosa and Kamashi zones, Ethiopia. Galore International Journal of Applied Sciences and Humanities, 1: 27-31.

Korobkon, A., T. Tegegn and C. Dilbo. 1985. Chemical control of bacterial leaf spot of hot pepper (Capsicum annuum L.) Caused by Xanthomonas campestris pv. vesicatoria. Scientific Phytopathological Laboratory (SPL) progress Report for the period, 86: 192-99.

Lemma, D. 2002. Tomatoes; Research experiences and production prospects. EARO Report. No. 43. Addis Ababa, Ethiopia.

Leslie, J. F. and B. A. Summerell. 2008. The Fusarium Laboratory Manual. John Wiley \& Sons.

Mehrotra, R. S. and A. Aggarwal. 2003. Rots, Damping offs, Downy mildews and White Rusts. In, Plant Pathology. Tata McGraw-Hill Publishing Company Limited. New Delhi, India.

Mekonen, S. and A. Chala. 2014. Assessment of hot pepper (Capsicum species) diseases in southern Ethiopia. International Journal of Science and Research, 3: 91-95.

Mengist, Y., D. Tadesse and A. Birara. 2019. Assessment

\section{CONFLICT OF INTEREST}

The authors have not declared any conflict of interests.

\section{AUTHORS CONTRIBUTIONS}

All the authors contributed equally to this work. of prevalence, incidence and severity of red pepper disease in Capsicum frutescens L. at central Gondar, Ethiopia. Journal of Academia and Industrial Research, 8: 45-53.

Mihajlovic, M., E. Rekanovic, J. Hrustic, M. Grahovac and B. Tanovic. 2017. Methods for management of soilborne plant pathogens. Pesticidi i fitomedicina, 32: 9-24.

Mulaa, M., E. Negussie, H. Mibei, D. Onyango, M. Bateman, A. Wood and J. Dougoud. 2018. Study on crop protection where the 'Green Innovation Centres for the Agriculture and Food Sector'(GIAE) initiative is being implemented. CAB International.

Rather, T. R., V. K. Razdan, A. K. Tewari, E. Shanaz, Z. A. Bhat, M. G. Hassan and T. A. Wani. 2012. Integrated management of wilt complex disease in bell paper (Capsicum annuum L.). Journal of Agricultural Science, 4: 141-47.

Sadessa, K., T. Hunduma and M. Assefa. 2016. Characterization and evaluation of hot pepper (Capsicum annuum L.) cultivars against bacterial wilt disease (Ralstonia solanacearum).

SAS. 2015. SAS 9.4® Intelligence Platform: System Administration Guide Statistical Analysis System. SAS institute. Inc. Cary. North Carolina, USA.

Tameru, A., J. Hamacher and H. W. Dehne. 2003. The increase in importance of Ethiopian Pepper mottle virus (EPMV) in the rift valley part of Ethiopia Time to create Awareness among researchers an extension workers. Pepper presented at Deutsches Tropentage.

Tripodi, P. and S. Kumar. 2019. The Capsicum Crop: An Introduction Compendium of Plant Genomes. Springer International Publishing. pp. 1-8.

Tucker, C. M. 1931. Taxonomy of the genus Phytophthora de BaryUniversity of Missouri Agricultural Experiment Station Research Bulletin.

Yandoc-Ables, C. B., E. N. Rosskopf and E. M. Lamb. 2007. Management of phytophthora crown rot in pumpkin and zucchini seedlings with phosphonates. Plant disease, 91: 1651-56. 
Publisher's note: EScience Press remains neutral with regard to jurisdictional claims in published maps and institutional affiliations.

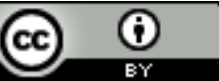

Open Access This article is licensed under a Creative Commons Attribution 4.0 International License, which permits use, sharing, adaptation, distribution and reproduction in any medium or format, as long as you give appropriate credit to the original author(s) and the source, provide a link to the Creative Commons license and indicate if changes were made. The images or other third-party material in this article are included in the article's Creative Commons license, unless indicated otherwise in a credit line to the material. If material is not included in the article's Creative Commons license and your intended use is not permitted by statutory regulation or exceeds the permitted use, you will need to obtain permission directly from the copyright holder. To view a copy of this license, visit http://creativecommons.org/licenses/by/4.0/. 